\title{
PENGARUH VARIABEL MAKRO EKONOMI DAN HARGA MINYAK DUNIA TERHADAP INDUSTRI HALAL'
}

\author{
Ali Mahdy Arrosikh \\ Departemen Ekonomi Syariah-Fakultas Ekonomi dan Bisnis-Universitas Airlangga \\ Email: alimahdyarrosikj96@gmail.com \\ Ilmiawan Auwalin \\ Departemen Ekonomi Syariah-Fakultas Ekonomi dan Bisnis-Universitas Airlangga \\ Email: auwalin@feb.unair.ac.id
}

\begin{abstract}
This paper aims to discover the influence of inflation rate, exchange rate, global's oil price and FDI toward halal industry in 48 OIC's member Countries. This research uses data by Statistical, Economic and Social Research and Training Centre for Islamic Countries (Sesric), world bank and Thomas Reuters with quantative approach and were analyzed by using panel data analysis. According to the result it is have positive significant influence to the halal industry in 48 OIC Countries. Inflation rate have a significant positive influant; exchange rate have a non significant positive influant; global's oil price have a significant negative influant; and FDI have a non-significant negative influant toward the increasing of the unemployment rate in 48 OIC's Countries.
\end{abstract}

Keywords: Halal Industry, Inflation, Exchange Rate, Global's Oil Price, FDI

\section{PENDAHULUAN}

Dalam beberapa tahun terakhir, seiring kenaikan jumlah umat muslim yang makmur, industri halal berkembang pesat menjadi sebuah penawaran gaya hidup yang mencakup semua aspek tingkatan urgensi maqashid syariah; dharuriyyah, hajiyyah, tahsiniyyah. Pembangunan ini dipicu oleh perubahan pola pikir konsumsi umat muslim dunia dan juga bergesernya etika konsumi masyarakat secara global.

Pada tahun 2016 dengan jumlah umat muslim di dunia yang berjumlah 1.8 miliar, industri halal memiliki estimasi nilai sekitar USD3 trilun (belum termasuk sektor jasa keuangan Islam), yang tumbuh dengan perkiraan rata-rata tahunan sebesar $20 \%$ yang memiliki nilai sekitar
USD560 miliar per tahunnya, membuat pertumbuhan industri halal ini menjadi salah satu segmen konsumer yang tumbuh paling cepat di dunia. Perkembangan cakupan industri halal sekarang tidak hanya sebatas pada sektor makanan, sekarang mencakup sektor farmasi, kosmetik, produk kesehatan, perlengkapan mandi juga merambah ke sektor jasa seperti logistik, pemasaran, media, pengemasan, branding, dan sektor finansial. (Fleishman Hillard Majlis 2011, Azmi dkk. 2013).

Dengan begitu besarnya kebutuhan masyarakat muslim yang berlandaskan maqashid syariah, membuat berbagai wirausahawan dan para cendikiawan muslim untuk berlomba

\footnotetext{
${ }^{1}$ Jurnal ini adalah bagian dari skrispi Ali Mahdy Arrosikh, NIM: 04151 1433160, yang diuji pada tanggal 26 Juli 2019.
} 
Arrosikh, et al/Jurnal Ekonomi Syariah Teori dan Terapan Vol. 6 No. 9 September 2019: 1840-1850; PENGARUH VARIABEL MAKRO EKONOMI DAN HARGA MINYAK DUNIA TERHADAP INDUSTRI HALAL

mengembangkan produk bisnis serta teknologi yang menunjang kebutuhan masyarakat berdasarkan aturan agama Islam. Berdasarkan penelitian Pew Research Center's Forum on Religion \& Public Life pada bulan April tahun 2017, populasi dunia diproyeksikan akan tumbuh sebesar $32 \%$ dalam beberapa dekade mendatang, jumlah Muslim diperkirakan akan meningkat sebesar $70 \%$ dari 1,8 miliar pada tahun 2016 menjadi hampir menjadi 3 miliar pada 2060. Pada tahun 2016, umat muslim membentuk $24.1 \%$ populasi dunia. Empat puluh lima tahun kemudian jumlah umat muslim dunia diperkirakan membentuk lebih dari tiga dari sepuluh orang populasi dunia (31.1\%).

Faktor-faktor yang membentuk pembangunan dan pertumbuhan industri halal dalam annual report GIEl Thomson Reuters ada empat, Finansial yang menopang industri halal (modal, financial); Pengaturan pemerintah terhadap industri halal (governance); Kesadaran masyarakat (awareness); dan keadaan sosial masyarakat (social). Empat komponen berbeda yang dipilih untuk membentuk indikator GIEI ditentukan berdasarkan garis utama unsur yang membentuk industri halal dan didasarkan pada isu-isu kontemporer yang meliputi empat komponen di atas.

Selain empat komponen utama di atas, ada banyak variabel yang ikut mempengaruhi pertumbuhan dan perkembangan industri halal baik secara langsung maupun tidak langsung. Seperti kondisi yang mempengaruhi langsung tingkat produksi dan konsumsi dalam suatu negara seperti volatilitas inflasi, nilai tukar, harga minyak dunia dan juga tingkat foreign direct investment. Variabel tersebut secara tidak langsung mempengaruhi paritas daya beli masyarakat dan tingkat produksi produk dari industri halal.

Berdasarkan latar belakang yang telah dikemukakan, maka dalam penelitian ini akan ditelaah dan dianalisis lebih lanjut mengenai isu pengaruh inflasi, nilai tukar, harga minyak dunia dan FDI terhadap industri halal pada 48 negara OKI.

\section{LANDASAN TEORI DAN PENGEMBANGAN HIPOTESIS}

\section{Industri Halal}

Berdasarkan penelitian gabungan dari Thomson Reuters dan DinarStandard pada tahun 2015, Terdapat 8 faktor makro utama yang terus mendorong pertumbuhan serta perkembangan industri halal yaitu:

1. Pertumbuhan demografi muslim.

2. Pertumbuhan ekonomi Islam global.

3. Adanya penerapan nilai-nilai islam pada gaya hidup dan praktik bisnis.

4. Adanya penerapan nilai-nilai islam pada gaya hidup dan praktik bisnis.

5. Partisipasi perusahaan multinasional.

6. Partisipasi negara maju dalam pertumbuhan pasar. 
7. Pentingnya bisnis yang berkelanjutan dalam sektor makanan, kevangan, pendidikan dan lingkungan.

8. Teknologi.

Inflasi

$\mathrm{BI}$ (2016) menjelaskan bahwa "indikator yang sering digunakan untuk mengukur tingkat inflasi adalah Indeks Harga Konsumen (IHK). Perubahan IHK dari waktu ke waktu menunjukkan pergerakan harga dari paket barang dan jasa yang dikonsumsi masyarakat". Mankiw (2006:31) menjelaskan bahwa "Indeks harga konsumen adalah indeks harga yang paling sering dipakai, tetapi bukan satusatunya indeks. Masih ada indeks harga produsen, yang mengukur harga sekelompok barang yang dibeli oleh perusahaan, bukan konsumen".

Menurut para ahli ekonomi dan ekonomi Islam, inflasi berdampak buruk pada perekonomian. Inflasi dapat menimbulkan gangguan pada fungsi vang sebagai fungsi tabungan, fungsi pembayaran di muka dan fungsi unit perhitungan.

Heitger (1985) menemukan adanya hubungan yang positif signifikan antara tingkat dan variabilitas atau dispersi inflasi dan hubungan yang negatif signifikan antara variabilitas inflasi dengan pertumbuhan ekonomi. Hal ini mengindikasikan bahwa inflasi merusak pertumbuhan ekonomi pada sektor industri dalam skala besar dan di negara berkembang selama 1950-1980 dan tidak ada pengucualian terhadap industri halal.

\section{Nilai Tukar}

Kurs atau nilai tukar adalah suatu nilai yang menunjukkan jumlah nilai mata vang dalam negeri yang diperlukan untuk mendapatkan satu unit mata vang asing (Sukirno, 2006:237). Sedangkan menurut Nopirin (1997:185) nilai tukar merupakan harga pertukaran antara dua mata vang yang berbeda dengan perbandingan nilai/harga tertentu.

Salah satu teori yang menjelaskan hubungan antara tingkat harga atau inflasi dengan pergerakan nilai tukar adalah teori paritas daya beli (Purchasing Power Parity Theory). Dalam teori paritas daya beli ini dikatakan bahwa nilai tukar antara dua negara seharusnya sama dengan rasio dari tingkat harga di kedua negara tersebut. Sehingga jatuhnya daya beli domestik pada suatu mata vang (meningkatnya tingkat harga domestik atau meningkatnya inflasi) akan diikuti oleh depresiasi pada mata vang negara tersebut di pasar vang luar negeri.

Dalam kenyataannya, biaya transportasi maupun hambatan perdagangan tidaklah dapat diabaikan. Dalam versi relatifnya, teori PPP mengubah pernyataan tingkat harga dan tingkat kurs keseimbangan menjadi "perubahan harga" dan "perubahan" kurs keseimbangan (Salvatore, 1997:128).

\section{Harga Minyak Dunia}

Harga minyak dunia adalah harga spot pasar minyak dunia berdasarkan standar West Texas Intermediate yang terbentuk dari akumulasi permintaan dan 
Arrosikh, et al/Jurnal Ekonomi Syariah Teori dan Terapan Vol. 6 No. 9 September 2019: 1840-1850; PENGARUH VARIABEL MAKRO EKONOMI DAN HARGA MINYAK DUNIA TERHADAP INDUSTRI HALAL

penawaran yang diperdagangkan pada New York Mercantile Exchange (NYMEX). Menurut Witjaksono (2010), harga minyak yang naik disebabkan oleh OPEC yang berpegang pada kuota produksi minyak mentah yang telah disepakati, untuk mencegah harga minyak tidak jatuh.

Dalam perspektif makroekonomi, peningkatan harga BBM akan cenderung diikuti oleh penurunan volume produksi berbagai kelompok industri dan sektor perekonomian lainnya, termasuk industri halal. Perubahan tersebut secara agregat akan menyebabkan turunnya total produksi/pendapatan nasional dan mendorong peningkatan pengangguran. Kondisi tersebut merupakan kondisi yang tentunya tidak diharapkan baik oleh pemerintah, masyarakat maupun pengusaha. Mankiw (2003) menjelaskan bahwa dalam perekonomian kerapkali terjadi fluktuasi dalam jangka pendek. Fluktuasi tersebut akan mempengaruhi keseimbangan pendapatan nasional, kesempatan kerja, dan tingkat harga.

\section{Foreign Direct Investment}

Menurut World Bank, FDI mengacu pada arus masuk investasi untuk memperoleh kepentingan manajemen yaitu sebesar minimum 10 persen atau lebih dari saham voting dalam suatu perusahaan. Hal ini dilihat sebagai gabungan dari persediaan modal dan teknologi, dan dapat menambah pengetahuan yang ada di tuan rumah atau negara tujuan, dalam perekonomian melalui pelatihan tenaga kerja, akuisisi keterampilan, pengenalan praktik manajerial baru dan pengaturan organisasi (De Mello, 1999).

Unsur fundamental dalam investasi perspektif Islam mencakup hal-hal sebagai berikut:

1. Investasi pada objek halal atau haram.

2. Akad investasi.

3. Larangan riba.

4. Larangan gharar.

5. Larangan bisnis yang tidak beretika Investasi asing diproksikan dengan foreign direct investment. Investasi asing memiliki hubungan langsung dua arah dengan pertumbuhan ekonomi, yang mencakup di dalamnya pertumbuhan industri halal juga. Ketika investasi asing di suatu negara tinggi, maka akan meningkatkan pertumbuhan ekonomi. Hubungan sebaliknya juga menunjukkan hubungan positif. Ketika hal ini terjadi, hal ini menjadi stimulus bagi investor asing menanamkan modal ke negara tersebut (Omri dan Kahouli, 2014; Nistor, 2014; Szkorupova, 2014; A.Omri dkk, 2014; Abbes dkk, 2015; Fadhil dan Almsafir, 2015; Lin dan Benjamin, 2018).

\section{METODE PENELITIAN}

Penelitian ini menggunakan pendekatan penelitian kuantitatif deskriptif untuk menjawab rumusan masalah serta tujuan penelitian yaitu pengaruh inflasi, nilai tukar, harga minyak dunia dan FDI terhadap industri halal di Negara OKI. Dalam penelitian ini populasinya adalah seluruh negara OKI yang memiliki indeks industri halal yang 
digambarkan oleh GIEl, kemudian juga yang terdapat / bisa diakses indeks inflasi dan nilai tukarnya.

Data yang diperoleh dalam penelitian ini merupakan data sekunder yang berasal dari sumber lain yang sudah tersedia. Data tersebut diambil dari laporan DinarStandard, SESRIC OICStat dan NYMEX. Data yang digunakan bersifat data panel atau polling data, yaitu data yang merupakan gabungan antara data time series dan cross section data. Penelitian ini memadukan data time series selama kurun waktu lima tahun mulai tahun 2014 hingga 2017.

Teknik estimasi yang digunakan dalam penelitian ini adalah metode regresi data panel. Data panel merupakan gabungan dari data cross section dan data time series.

dapat dirumuskan hipotesis dalam penelitian ini adalah sebagai berikut:

$\mathrm{H1}$ : inflasi, nilai tukar, harga minyak dunia dan FDI secara parsial berpengaruh signifikan terhadap Industri Halal di 48 Negara OKI.

H2 : inflasi; nilai tukar; harga minyak dunia; dan FDI secara simultan berpengaruh signifikan terhadap Industri Halal di 48 Negara OKI.

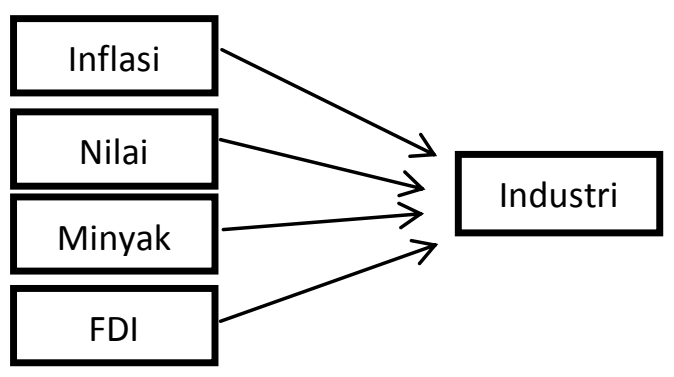

\section{Gambar 1.}

\section{Model Hipotesis}

\section{HASIL DAN PEMBAHASAN}

\section{Analisis Deskriptif}

Pada table 1 hasil statistik deskriptif menunjukkan bahwa rata-rata kenaikan indeks GIEl 48 negara OKI sebesar 22.94823 satuan indeks selama 4 tahun. Nilai minimum dan maksimum masingmasing sebesar .9 dan 146.21 satuan indeks dengan standar deviasi sebesar 22.73329 satuan indeks. Hal ini menunjukkan ketidakmerataan tingkat industri halal pada 48 negara OKI (standar deviasi yang tinggi), dikarenakan obyek penelitian yang bercampur antara negara-negara least developing, developing kemudian bercampur negaranegara dengan tingkat income low, middle dan high.

Tabel 1.

Hasil Uji Statistik Deskriptif

\begin{tabular}{|l|c|c|c|c|l|}
\hline \multicolumn{1}{|c|}{ Variabel } & Mean & Std.Dev. & Min & Max & Observasi \\
\cline { 1 - 5 } GIEIINDEX & 22.94823 & 22.73329 & .9 & 146.21 & $\mathrm{~N}=192$ \\
\cline { 1 - 5 } INF & 2.674792 & 7.523296 & -25.96 & 33.9 & $\mathrm{n}=48$ \\
\cline { 1 - 5 } EX & 1502.806 & 4765.451 & .28 & 33226.3 & \multirow{2}{*}{$\mathrm{T}=4$} \\
\cline { 1 - 4 } OIL & 58.9925 & 20.03673 & 43.14 & 93.26 & \\
\cline { 1 - 5 } FDI & 3.634271 & 4.818937 & -4.85 & 29.47 & \\
\hline
\end{tabular}

Sumber : data sekunder yang diolah (2019)

Selanjutnya pada variabel independen inflasi yang diproksikan oleh GDP deflator memiliki rata-rata sebesar $2.674792 \%$. Nilai minimum dan maksimum masing-masing sebesar $-25.96 \%$ dan $33.9 \%$ dengan standar deviasi $7.523296 \%$. Hal ini 
menjelaskan bahwa selisih tingkat inflasi anatara 48 negara OKI sangat tinggi, khususnya negara-negara yang termasuk negara less developing.

Untuk variabel nilai tukar per US Dollar rerata yang didapat sebesar 1502.806 satuan dengan standar deviasi sebesar 4765.451 satuan. Nilai minimum yang ditampilkan sebesar .28 satuan dan nilai maksimum sebesar 33226.3 satuan. Hal ini menunjukkan tingkat daya beli dengan mata vang masing-masing negara OKI terhadap dollar sangat beragam.

Kemudian harga minyak dunia yang pada setiap negara terkena harga yang sama, didapat rerata harga minyak selama 4 tahun sebesar USD. 58.9925 dan USD. 20.03673 untuk besaran standar deviasinya. Nilai minimum yang diperoleh sebesar USD. 43.14 dan USD. Untuk nilai maksimumnya. Hal ini menunjukkan bahwa harga minyak dunia dalam 4 tahun terakhir berubah dengan cepat.

Foreign direct investment dari tahun 2014 sampai 2017 menunjukkan hasil yang cukup bersimpangan antar 48 negara OKI. Nilai rata-rata FDI 48 negara OKI sebesar $3.634271 \%$ dengan standar

\begin{tabular}{|l|l|l|}
\hline Variabel & t-statistik & Prob. \\
\hline Inf & .2687573 & 0.000 \\
\hline Ex & .0004628 & 0.307 \\
\hline Oil & -.0270616 & 0.052 \\
\hline Fdi & -.0839235 & 0.466 \\
\hline
\end{tabular}

deviasi sebesar $4.818937 \%$. nilai minimum FDI sebesar $-4.85 \%$ dan nilai maksimum sebesar $29.47 \%$ kontribusinya terhadap
GDP. Hal ini menunjukkan besarnya perbedaan investasi asing yang ada pada 48 negara OKI.

\section{Analisis Model Regresi}

Tabel 2.

Hasil Regresi Data Panel-Random Effect Model

\begin{tabular}{|l|l|l|l|l|}
\hline \multirow{2}{*}{ Variabel } & \multicolumn{4}{c|}{ Model regresi } \\
\cline { 2 - 5 } & \multicolumn{1}{|c|}{ Koefisien } & \multicolumn{1}{c|}{ t-statistik } & \multicolumn{1}{c|}{ Sig. } & Kesimpulan \\
\hline Const. & 23.43529 & 6.73 & 0.000 & Signifikan \\
\hline Inf & .2687573 & 5.42 & 0.000 & Tidak sig. \\
\hline Ex & .0004628 & 1.02 & 0.307 & Tidak sig. \\
\hline Oil & -.0270616 & -1.94 & 0.052 & Signifikan \\
\hline Fdi & -.0839235 & -0.73 & 0.466 & Signifikan \\
\hline R & & & signifikan pada tingkat kepercayaan 90\% \\
\hline F. Sig. & 0.0013 & & & \\
\hline
\end{tabular}

Sumber: Stata 14,2 (data diolah)

\section{Uji F (Simultan)}

Berdasarkan hasil regresi data panel menggunakan software stata 14,2 menunjukkan hasil uji $F$ pada tabel, $F$ statistik menunjukkan angka 0,0000 lebih kecil dari $a=0,05$ maka dapat disimpulkan bahwa $\mathrm{HO}$ ditolak dan $\mathrm{HI}$ diterima sehingga variabel tingkat inflasi yang diproksikan oleh GDP deflator, nilai tukar, harga minyak dunia dan foreign direct investment berpengaruh signifikan secara simultan terhadap indeks industri halal pada 48 negara OKI.

\section{Uji † (Parsial)}

\section{Tabel 3.}

\section{Hasil Regresi t-statistik-Random Effect Model}

Sumber: Stata 14,2 (data diolah) Berdasarkan hasil uji † pada tabel 4.3, maka interpretasi hasil sebagai berikut: 
1. Tingkat inflasi yang diproksikan dengan GDP (Inf) memiliki t-statistik sebesar .2687573 dengan tingkat signifikansi sebesar 0.000 yang berarti lebih kecil dari a 0,1 sehingga Tingkat inflasi yang diproksikan dengan GDP memiliki hubungan positif dan berpengaruh signifikan terhadap indeks GIEl pada 48 negara OKI.

2. Nilai tukar (Ex) memiliki t-statistik sebesar .0004628 dengan tingkat signifikansi sebesar 0.307 yang berarti lebih besar dari a 0,1 sehingga Nilai tukar (Ex) memiliki hubungan positif dan tidak berpengaruh $\mathrm{n}$ signifikan terhadap indeks GIEl pada 48 negara OKI.

3. Harga minyak dunia (Oil) memiliki tstatistik sebesar -.0270616 dengan tingkat signifikansi sebesar 0.052 yang berarti lebih besar dari a 0,1 sehingga PDRB memiliki hubungan negatif dan berpengaruh signifikan terhadap indeks GIEl pada 48 negara OKI.

4. Foreign direct investment memiliki nilai t-statistik sebesar -.0839235 dengan tingkat signifikansi sebesar 0.466 yang berarti lebih besar dari a 0,1 sehingga Foreign direct investment memiliki hubungan negatif dan tidak berpengaruh signifikan terhadap indeks GIEl pada 48 negara OKI.

\section{Koefisien Determinasi R2}

Berdasarkan tabel, diketahui bahwa nilai koefisien determinasi atau Rsquare pada penelitian ini sebesar 0.0013 atau $.13 \%$, sehingga dapat disimpulkan bahwa variabel independen yang terdiri dari tingkat inflasi yang diproksikan oleh GDP deflator, nilai tukar, harga minyak dunia dan foreign direct investment pada 48 negara OKI dapat menjelaskan pengaruhnya terhadap indeks GIEI investment pada 48 negara OKI tahun 2014 sampai 2017 sebesar $0.13 \%$, sedangkan sisanya dijelaskan oleh variabel lain diluar model.

\section{Hubungan inflasi yang diproksikan dengan GDP deflator dengan indeks GIEI 48 negara OKI.}

Pada pembahasan kali ini sesuai dengan hasil regresi data panel pada sub bab sebelumnya, ditemukan bahwa inflasi yang diproksikan dengan GDP deflator berpengaruh signifikan positif terhadap indeks GIEl 48 negara OKI. Hal ini menunjukkan bahwa ketika bahwa inflasi yang diproksikan dengan GDP deflator meningkat, maka indeks GIEl 48 negara OKI akan naik. Sebaliknya, ketika bahwa inflasi yang diproksikan dengan GDP deflator menurun, maka indeks GIEl 48 negara OKI akan turun.

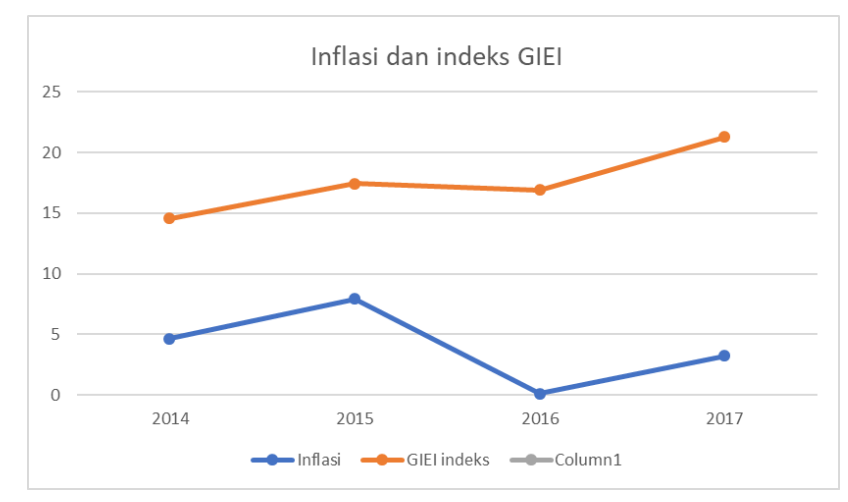

Gambar 2.

Perbandingan tingkat inflasi dan industri halal pada negara Maldives 2014-2017

Seperti yang terjadi pada gambar. Di negara Maldives ketika inflasi naik maka 
indeks GIEl akan naik pada tahun 2015, sebaliknya pada tahun 2016 ketika inflasi turun maka indeks GIEl pada tahun 2016 juga turun. Hasil yang dinyatakan oleh statistik data 48 negara menunjukkan bahwasannya hal ini tidak sesuai dengan teori inflasi pada umumnya.

Meskipun tidak sesuai dengan teori inflasi pada umumnya, hasil ini sejalan dengan penelitian Gillman (2003) yang menjadikan negara Amerika dan Inggris sebagai obyek penelitiannya. Dengan melakukan uji kointegrasi dalam penelitiannya, mendapatkan hasil bahwa percepatan inflasi menyebabkan naiknya rasio upah riil terhadap tingkat bunga riil yang menunjukkan bahwa inflasi memiliki hubungan positif terhadap pertumbuhan ekonomi walaupun, tingkat pertumbuhan output mengalami penurunan pertumbuhan oleh inflasi.

\section{Hubungan nilai tukar (Ex) dengan indeks GIEI pada 48 negara OKI.}

Pada pembahasan kali ini sesuai dengan hasil regresi data panel pada sub bab sebelumnya, ditemukan bahwa nilai tukar berpengaruh positif tetapi tidak signifikan terhadap indeks GIEl pada 48 negara OKI. Hal ini menunjukkan bahwa ketika bahwa nilai tukar menurun, maka indeks GIEI akan turun. Sebaliknya, ketika bahwa nilai tukar meningkat, maka indeks GIEl akan naik.

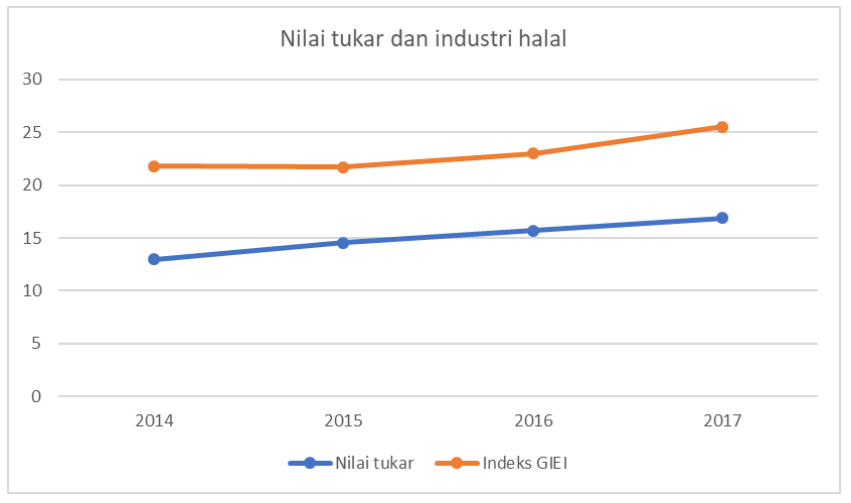

Gambar 3.

Perbandingan tingkat nilai tukar dan industri halal pada 48 negara OKI

Seperti gambar di atas, terlihat bahwa pada tahun 2015 sampai dengan 2017 tren antara indeks GIEl dan nilai tukar memiliki tren yang sama, dan pada 2014 ke 2015 meskipun indeks GIEl konstan nilai tukar terhadap US dollar pada 48 negara OKI menunjukkan kenaikan. Hal itu menunjukkan bahwa nilai tukar berpengaruh positif tetapi tidak signifikan. Hubungan positif yang ditunjukkan hasil uji di atas bertolak belakang dengan banyak penelitian terdahulu, kecuali dengan hasil penelitian Horas (2017) yang menunjukkan hubungan positif nilai tukar dan pertumbuhan ekonomi.

\section{Hubungan harga minyak dunia dengan indeks GIEl pada 48 negara OKI.}

Pada pembahasan kali ini sesuai dengan hasil regresi data panel pada sub bab sebelumnya, ditemukan bahwa harga minyak dunia berpengaruh signifikan negatif terhadap indeks GIEl pada 48 negara OKI. Hal ini menunjukkan bahwa ketika bahwa harga minyak dunia meningkat, maka indeks GIEl akan menurun. Sebaliknya, ketika bahwa harga 
minyak dunia menurun, maka indeks GIEI akan meningkat.

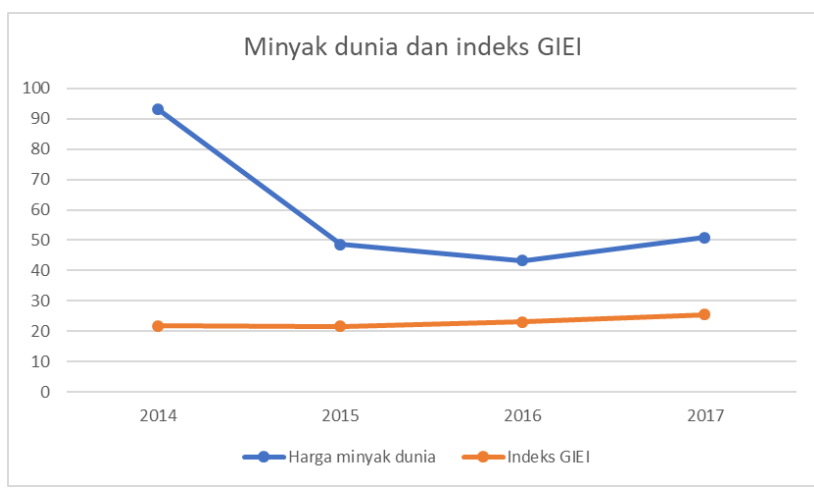

Gambar 4.

Perbandingan tingkat harga minyak dunia dan industri halal pada 48 negara OKI

Gambar di atas menunjukkan bahwa pada tahun 2014 hingga 2017 ketika harga minyak dunia turun indeks GIEI mengalami kenaikan, meskipun dari tahun 2016 ke 2017 ketika harga minyak dunia naik indeks GIEl tetap naik. Dikarenakan banyaknya transmisi harga minyak dunia terhadap aktivitas ekonomi, hasil uji yang didapatkan oleh peneliti lain pun banyak berbeda, setidaknya ada 6 transmisi harga minyak terhadap aktivitas ekonomi:

1. Efek sisi penawaran (supply-side shock effect), Dogrul (2015).

2. Efek transfer kekayaan (wealth transfer effect), Cologni (2008).

3. Efek saldo riil (real balance effect), Tang dkk (2010).

4. Efek inflasi (inflation effect), Cologni (2008).

5. Efek konsumsi, Sadorsky (2011).

6. Efek penyesuaian sektoral (sectoral adjustment effect), Dogrul (2010).

4.3.4 Hubungan foreign direct investment (FDI) dengan indeks GIEI pada 48 negara OKI.
Hubungan foreign direct investment (FDI) dengan indeks GIEl pada 48 negara OKI.

Pada pembahasan kali ini sesuai dengan hasil regresi data panel pada sub bab sebelumnya, ditemukan bahwa FDI berpengaruhn negatif tetapi tidak signifikan terhadap indeks GIEl pada 48 negara OKI. Hal ini menunjukkan bahwa ketika bahwa FDI meningkat, maka indeks GIEl akan menurun. Sebaliknya, ketika bahwa FDI menurun, maka indeks GIEl akan meningkat.

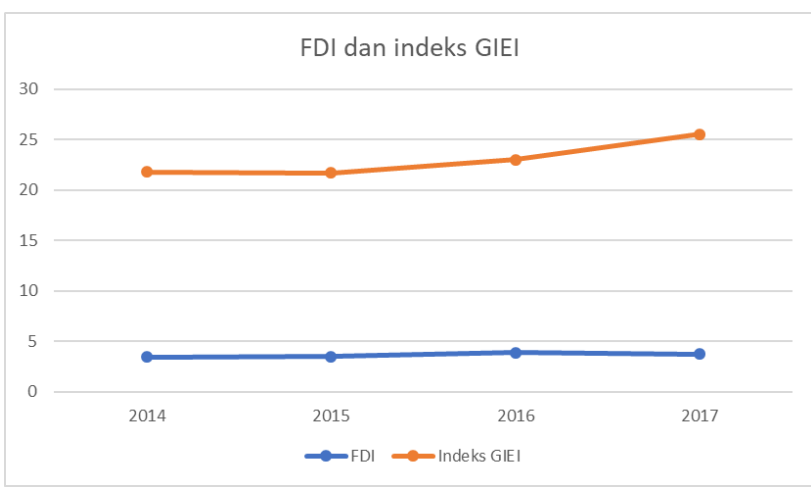

Gambar 5.

Perbandingan FDI dan industri halal pada 48 negara OKI

Gambar di atas menjelaskan memang ada hubungan negatif antara FDI terhadap indeks GIEl akan tetapi tidak signifikan. Penelitian yang dilakukan Hailu (2010) FDI menunjukkan hubungan positif dengan pertumbuhan ekonomi dengan perantara peningkatan produktivitas industri.

\section{Simpulan}

Berdasarkan latar belakang, rumusan masalah, pembahasan dan analisis sebelumnya, maka kesimpulan dari penelitian ini yaitu:

1. Inflasi yang diproksikan dengan GDP deflator terhadap indeks GIEl memiliki 
hubungan positif dan berpengaruh signifikan terhadap indeks GIEl pada 48 negara OKI.

2. Nilai tukar memiliki hubungan positif dan tidak berpengaruh signifikan terhadap indeks GIEl pada 48 negara OKI.

3. Harga minyak dunia memiliki hubungan negatif dan berpengaruh signifikan terhadap indeks GIEl pada 48 negara OKI.

4. Foreign direct investment memiliki hubungan negatif dan tidak berpengaruh signifikan terhadap indeks GIEl pada 48 negara OKI.

5. Inflasi yang diproksikan dengan GDP deflator kemudian nilai tukar, harga minyak dunia dan FDI berpengaruh signifikan secara simultan terhadap indeks GIEl pada 48 negara OKI.

\section{Saran}

Bagi penelitian selanjutnya, penelitian ini mengkaji determinan indeks GIEl pada 48 negara OKI dari aspek ekonomi. Diharapkan pada penelitian selajutnya, memperluas determinan atau aspek yang diteliti.

1. mempengaruhi indeks GIEI sehingga analisis dan kajian lebih mendalam dan komprehensif. Perlu juga mempertimbangkan dan mengkaji dimensi waktu dan ruang lingkup penelitian.

2. Bagi negara-negara OKI dan OKI, diharapkan mampu menerapkan kebijakan yang tepat dan sesuai agar dapat meningkatkan indeks GIEI.

\section{DAFTAR PUSTAKA}

Abdullah, Boedi, \& Saebani, Beni Ahmad. 2014. Metode Penelitian Ekonomi Islam. Bandung: Pustaka Setia.

Arsyad, Lincolin. 2010. Ekonomi Pembangunan. Yogyakarta: UPP STIM YKPN.

Aziz, Yuhanis Abdul \& Nyen Yui Chok. 2012. "The Role of Halal Awareness, Halal Certification, and Marketing Components in Determining Halal Purchase Intention among NonMuslims in Malaysia: A Structural Equation Modeling Approach". Journal of International Food \& Agribusiness Marketing, 25:1-23.Arif. 2014. Metode Penelitian. Medan: Universitas Negeri Medan.

Chapra, M. Umer, 1992. Islam and Economic Challange. The Islamic Foundation and International Institute of Islamic Thought, London and Herndon.

Cologni, A and M. Manera. (2008). Oil Prices, Inflation and Interest Rates in a Structural Cointegrated VAR Model for the G-7 Countries. Energy Economics (30). pp. 856888.

Doğrul, H. G. and U. Soytas. (2010). Relationship between Oil Prices, Interest Rate, and Unemployment: Evidence from an Emerging Market. Energy Economics (32), pp. 1523- 1528. 
Elasrag, Hussein. 2016. Halal Industri: Key Challanges and Opportunities. Munich Personal RePec Archive

Gillman, Max, and Anton Nakov, 2003, A Revised Tobin Effect from Inflation: Relatif Input Price and Capital Ratio Realignments, US and UK, 1959-1999, Economica Vol 70 No. 279 (August 2003

Gokal, Vikesh and Subrina Hanif (2004), Relationship Between Inflation and Economic Growth, Bank Of Fiji, Working Paper.

Gujarati, Damodar N.1991. Ekonometrika Dasar Edisi Ketiga Terjemahan. Jakarta : Erlangga.

Hailu, Z.H. (2010). Impact of Foreign Direct Investment on Trade of African Countries. International Journal of Economics and Finance Vol. 2, No. 3; $\quad$ August 2010. www.ccsenet.org/ijef.

Huda, Nurul dkk. 2008. Ekonomi Makro Islam: Pendekatan Teoritis. Edisi Pertama. Jakarta : Kencana Prenada Media Grup

Kamali, Mohammad Hashim. 2013. The Parameters of Halal and Haram in Shariah and the Halal Industri. London: The International Institute of Islamic Thought

MIFC. 2015. Halal Ecosystem Prospects for Global Growth. Malaysia : MIFC

Mukhtar, A. And Butt, M.M. (2012), "Intention to choose Halal products: the role of religiosity", Journal of Islamic Marketing, Vol. 3 No. 2, pp. 108-120.

P3El. 2012. Ekonomi Islam. Jakarta: PT. Raja Grafindo Persada

Sadorsky, P. (1999). Oil Price Shocks and Stock Market Activity. Energy Economics (21), pp. 449 - 469.

Tang, W; L.Wu, Libo and Z.X. Zhang. (2010). Oil Price Shocks and their Shortand Long-Term Effects on the Chinese Economy. Energy Economics (32), pp. S3-S14.

Thomson Reuters. 2013. State of The Global Islamic Economy 2013 Report.

Dubai : Thomson Reuters . 2014. State of The Global Islamic Economy 2014/2015 Report. Dubai : Thomson Reuters. 2015. State of The Global Islamic Economy 2015/2016 Report. Dubai : Thomson Reuters. 2016. State of The Global Islamic Economy 2016/2017 Report. Dubai : Thomson Reuters. 2017. State of The Global Islamic Economy 2017/2018 Report. Dubai : Thomson Reuters. 2018. State of The Global Islamic Economy 2018/2019 Report. Dubai : Thomson Reuters.

Todaro, Michael P. dan Stephen C. Smith. 2004. Pembangunan Ekonomi di Dunia Ketiga. Edisi Kedelapan. Jakarta : Penerbit Erlangga 